\title{
From goat colostrum to milk: Physical, chemical, and immune evolution from partum to 90 days postpartum
}

\author{
D. Sánchez-Macías, ${ }^{*}$ I. Moreno-Indias, † N. Castro,‡ A. Morales-delaNuez,§ and A. Argüello ${ }^{1}$ \\ *Department of Agroindustrial Engineering, Universidad Nacional de Chimborazo, Riobamba EC060150, Ecuador \\ †Endocrinology and Nutrition Unit, Hospital Clínico Virgen de la Victoria, Malaga 29010, Spain \\ $\ddagger$ Department of Animal Science, Universidad de Las Palmas de Gran Canaria, Arucas 35413, Spain \\ §Facultad de Ciencia Pecuarias, Escuela Superior Politécnica de Chimborazo, Riobamba EC060150, Ecuador
}

\begin{abstract}
This study focused on the study of the changes originated in the milk from partum until d 90 of lactation. Ten multiparous Majorera goats, bred carefully under animal health standards, with a litter size of 2 kids (the average in this breed is 1.83 prolificacy) and similar gestation length $(149 \pm 1 \mathrm{~d})$ were used. Goat kids were removed from their dams to avoid interferences with the study. Compositional content (fat, protein, and lactose) were measured, as well as some other properties, including $\mathrm{pH}$, density, titratable acidity, ethanol stability, rennet clotting time, and somatic cell count. Moreover, immunity molecules (IgG, IgA, and IgM concentrations and chitotriosidase activity) received great attention. Fat and protein content were higher in the first days postpartum, whereas lactose content was lower. Density, titratable acidity, rennet clotting time, and somatic cell count decreased throughout the lactation period, whereas $\mathrm{pH}$ and ethanol stability increased. Relative to the immunological parameters, each measured parameter obtained its maximum level at $\mathrm{d}$ 0, showing the first milking as the choice to provide immunity to the newborn kids. On the other hand, this study might be used to establish what the best use is: processing or kid feeding.
\end{abstract}

Key words: goat colostrum, milk composition, immunological parameter, technological property

\section{INTRODUCTION}

Colostrum is the initial milk secreted by mammals during parturition and the first few days after birth. It provides protection to the immune system of newborns and provides passive immunity against pathogens. The transition period is marked by nutritional, metabolic, hormonal, and immunological changes that have an effect on the incidence of infections and meta-

Received March 14, 2013.

Accepted September 9, 2013.

${ }^{1}$ Corresponding author: aarguello@dpat.ulpgc.es bolic diseases. During the transition from colostrum to normal milk, gradual or sometimes sudden changes may occur in composition and properties (Arain et al., 2008). Tsioulpas et al. (2007) reported changes in physical and technological parameters from colostrum to milk in cows, and Argüello et al. (2006) observed that caprine colostrum exhibits some extreme physical properties. Abd El-Fattah et al. (2012) reported in buffalo and cows that the compositions of both colostrums approach those of normal milk within $5 \mathrm{~d}$ after parturition. Some studies have focused on the composition of goat milk through the lactation curve (DelgadoPertíñez et al., 2009); Argüello et al. (2006) described how the number of lactations and litter size affect the immune and physical goat colostrum characteristics until $5 \mathrm{~d}$ postpartum. But to our knowledge, no studies about immune characteristics are available as far as $5 \mathrm{~d}$ postpartum of dairy goats.

Complete knowledge of the changes occurring in the lactation period is critical for the establishment of milk quality criteria, as part of the payment system for milk, which will ensure better quality of the final dairy products (Raynal-Ljutovac et al., 2005). Those authors reported some observations, such as the legislationrestricted $\operatorname{IgG}$ content in milk because of the negative effects of colostrum on cow milk (e.g., less-effective pasteurization, decreased heat stability of milk, and lower cheese yield and curd firmness). These effects were linked to the increase in total soluble protein content, and greatly depend on the colostrum addition. Indeed, Suchanek et al. (1978), when adding 10\% of colostrum from d 4 to 7 postpartum in cow milk, did not observe significant modification of parameters such as acidification ability, rennet coagulation, heat stability at $135^{\circ} \mathrm{C}$, and cheese-making parameters of Edam-type cheese. Zawistowski and Mackinnon (1993) reported that the presence of high levels of bovine IgG could adversely affect the human immune system. Argüello (2011) presented the most up-to-date trends in goat research, remarking that it needs to progress rapidly to reach the level of knowledge of other species such as cattle and sheep. Due to lack of information in goats, the aim 
of the present study was to evaluate the evolution of physical, chemical, and immune parameters in the goat transition period from colostrum to milk during the first $90 \mathrm{~d}$ postpartum.

\section{MATERIALS AND METHODS}

\section{Animals and Samples Collection}

Experimental animal procedures were approved by the Ethics Committee of the Universidad de Las Palmas de Gran Canaria (ULPGC, Arucas, Spain). Goat colostrum and milk samples were collected from the ULPGC farm at partum and each day postpartum at $0800 \mathrm{~h}$ from 10 Majorera dairy goats; the samples were transported to the laboratory and divided into 2 aliquots, one of which was stored at $4^{\circ} \mathrm{C}$ and the other at $-20^{\circ} \mathrm{C}$. Dairy goats enrolled in the present experiment had been through the dry period for 2 mo and did not show any health problems during the experimental period (weekly microbial tests and visual observations were performed for ensuring this statement). Goat colostrum and milk were measured using recording jars at the milking parlor and samples were collected on the first $5 \mathrm{~d}$ postpartum and then on selected days (d 15, 30,60 , and 90).

\section{Proximal Composition}

Fat, protein, lactose, colostrum DM and SNF, and milk content were determined by routine laboratory procedures using the automated infrared method (DMA2001 Milk Analyzer; Miris Inc., Uppsala, Sweden).

\section{Physical Properties}

The $\mathrm{pH}$ of the undiluted colostrum and milk was determined using a portable $\mathrm{pH}$ meter (Jenco model 6009 portable pH meter; Jenco Instruments Inc., San Diego, CA); pH determinations were made in triplicate. The density of the undiluted colostrum and milk was determined using a portable densitometer with a range between 1,000 to 1,100 g/L (Alla; Alla S.A., Madrid, Spain); density determinations were made in triplicate. The ethanol stability (ES) was determined according to Tsioulpas et al. (2007). The strongest concentration of ethanol that did not cause coagulation was defined as the ES. For the determination of acidity, titratable acidity analysis was performed. One milliliter of phenolphthalein indicator (concentrated) was added to 10 $\mathrm{mL}$ of milk and the mixture was titrated with $0.111 \mathrm{M}$ $\mathrm{NaOH}$ to a permanent faint pink color, which was the titration endpoint $(\mathrm{pH}$ 8.3). For rennet-clotting time
(RCT) evaluation, $5 \mathrm{~mL}$ of milk was poured into a glass test tube and maintained in a $30^{\circ} \mathrm{C}$ water bath. The sample was left at $30^{\circ} \mathrm{C}$ for $10 \mathrm{~min}$ and then 100 $\mu \mathrm{L}$ of freshly prepared rennin at $0.1 \mathrm{mg} / \mathrm{mL}$ (Sigma-Aldrich, St. Louis, MO) was added. The time (min) from thorough mixing to the first sign of sudden breakdown of the film on the test tube wall was measured and defined as the RCT. The SCC was determined using a DeLaval somatic cell counter (DeLaval International AB, Tumba, Sweden) immediately after samples were obtained, with a soak time of 1 min before the count, following the instructions of Sanchez-Macias et al. (2010a).

\section{Immunological Parameters}

$\operatorname{IgG}, \operatorname{Ig} A$ and $\operatorname{IgM}$ quantifications in colostrum and milk were performed using goat IgG, IgA, and IgM ELISA kits (Bethyl Laboratories, Montgomery, TX). Chitotriosidase (ChT) activity was measured according to Argüello et al. (2008) by incubating $1 \mu \mathrm{L}$ of undiluted colostrum or milk with $100 \mu \mathrm{L}$ of a $22 \mathrm{mM}$ solution of an artificial substrate (4-methylumbelliferyl$\mathrm{d}-\mathrm{N}, \mathrm{N}^{\prime}, \mathrm{N}^{\prime \prime}$ triacetylchitotriose) in $0.5 \mathrm{M}$ citrate phosphate buffer $\left(\mathrm{pH} \mathrm{5.2)} \mathrm{for} 15 \mathrm{~min}\right.$ at $37^{\circ} \mathrm{C}$. The reaction was stopped with $5 \mathrm{~mL}$ of $0.5 \quad M \mathrm{Na}_{2} \mathrm{CO}_{3}-\mathrm{NaHCO}_{3}$ buffer (pH 10.7). Fluorescence was measured with a fluorometer (PerkinElmer, Norwalk, CT), at 365-nm excitation and 450-nm emission. The ChT activity is expressed as nanomoles of substrate hydrolyzed per milliliter per hour.

\section{Statistical Analysis}

Statistical analyses were performed using SAS (version 9.00; SAS Institute Inc., Cary, NC). The SAS MIXED procedure for repeated measurements was used to evaluate the effect of postpartum time on the immune and physical parameters and proximate composition on colostrum and milk samples. The Tukey test was used to evaluate the differences during the evolution time at a significance level of $P<0.05$.

\section{RESULTS AND DISCUSSION}

\section{Proximal Composition}

The proximal composition is displayed in Table 1. Argüello et al. (2006) reported similar values and evolution in the same breed at $5 \mathrm{~d}$ postpartum. Fat percentage at partum was higher than d 2 and the following days. The fat percentage remained high until $d$ 5 and reached normal milk goat fat percentage at d 15 , in accordance with previous results for the same breed 
Table 1. Proximal composition, including fat, protein, lactose, DM, and SNF, of colostrum and milk samples from partum to d 90 postpartum (n = 10 Majorera-breed goats)

\begin{tabular}{|c|c|c|c|c|c|c|c|c|c|c|c|}
\hline \multirow[b]{2}{*}{ Item } & \multicolumn{10}{|c|}{ Days postpartum } & \multirow[b]{2}{*}{ SEM } \\
\hline & 0 & 1 & 2 & 3 & 4 & 5 & 15 & 30 & 60 & 90 & \\
\hline Fat, $\%$ & $7.70^{\mathrm{a}}$ & $6.86^{\mathrm{ab}}$ & $6.26^{\mathrm{b}}$ & $6.15^{\mathrm{b}}$ & $6.43^{\mathrm{b}}$ & $6.20^{\mathrm{b}}$ & $4.28^{\mathrm{c}}$ & $3.88^{\mathrm{c}}$ & $4.31^{\mathrm{c}}$ & $4.31^{\mathrm{c}}$ & 0.22 \\
\hline Lactose, \% & $2.44^{\mathrm{a}}$ & $3.53^{\mathrm{b}}$ & $4.15^{\mathrm{c}}$ & $3.98^{\mathrm{bc}}$ & $4.20^{\mathrm{c}}$ & $4.45^{\mathrm{c}}$ & $5.10^{\mathrm{d}}$ & $5.34^{\mathrm{d}}$ & $5.48^{\mathrm{d}}$ & $5.44^{\mathrm{d}}$ & 0.13 \\
\hline DM, \% & $21.57^{\mathrm{a}}$ & $18.36^{\mathrm{b}}$ & $16.17^{\mathrm{c}}$ & $16.83^{\mathrm{c}}$ & $16.88^{\mathrm{c}}$ & $16.54^{\mathrm{c}}$ & $13.68^{\text {de }}$ & $13.34^{\mathrm{e}}$ & $13.96^{\mathrm{de}}$ & $14.26^{\mathrm{d}}$ & 0.35 \\
\hline $\mathrm{SNF}, \%$ & $13.87^{\mathrm{a}}$ & $11.50^{\mathrm{b}}$ & $10.90^{\mathrm{c}}$ & $10.68^{\mathrm{c}}$ & $10.44^{\mathrm{cd}}$ & $10.34^{\mathrm{cd}}$ & $9.40^{\mathrm{d}}$ & $9.44^{\mathrm{d}}$ & $9.66^{\mathrm{d}}$ & $9.94^{\mathrm{d}}$ & 0.17 \\
\hline
\end{tabular}

${ }^{\mathrm{a} e} \mathrm{Means}$ within a row with different superscripts differ $(P<0.05)$.

(Sánchez-Macías et al., 2010b). According to Laakso et al. (1996), colostrum contained substantially less stearic and oleic acids and more myristic and palmitic acids than the normal milk fat; thus, the mixture of colostrum from d 3, 4, or 5 might change the normal FA distribution in milk, with consequences of goat cheese lipolysis. The protein percentage was reduced $45 \%$ at d 2 postpartum, but after that no significant differences were observed until d 5 postpartum. The protein content during this period consists of greater amounts of casein and globulin (Tsioulpas et al., 2007). Protein percentages after d 15 were lower percentages before $\mathrm{d}$ 15 and similar to those of the Tinerfeña breed (Capote, 1999) and Majorera breed goat milk (Sánchez-Macías et al., 2010b). Results in other breeds showed a similar decrease in total protein content in colostrum and in total protein levels (Graf et al., 1970; Linzell and Peaker, 1974). At partum, Csapó et al. (1994) found $16.2 \%$ total protein in colostrum from white Hungarian goats, Hadjipanayiotou (1995) observed $16.0 \%$ in colostrum from Damascus goats, and Chen et al. (1998) discovered $16.5 \%$ in colostrum from Nubian goats. Thus, differences between breeds are more pronounced in milk production, with total protein content being lower in high-producing breeds (Pritchett et al., 1991; Quigley et al., 1994). Lactose percentage displayed an increasing pattern, as has been described previously by Akinsoyinu et al. (1979), Hadjipanayiotou (1995), and Argüello et al. (2006) in different goat breeds. According to Ontsouka et al. (2003), lactose production causes water influx in milk through osmotic effects, and values observed by those authors in cows were lower in colostrum than in mature milk. However, these authors reported that concentrations of $\mathrm{Na}$ and $\mathrm{Cl}$, which are osmotically active molecules in milk, were elevated in colostrum compared with mature milk. Thus, the electrolyte transfer from blood into milk through leaky tight junctions (Nguyen and Neville, 1998) is expected to increase the milk volume during the colostral period despite relatively low lactose secretion. That may be the explanation to results regarding the volume produced (Table 2), which was greater at partum.

\section{Physical and Technological Properties and SCC}

Physical and technological characteristics, as well as SCC of goat colostrum and milk are displayed in Table 2 . The density decreased from partum to $90 \mathrm{~d}$ postpartum. The density curve profile was closer to that described by Rudovsky et al. (2008) for goat colostrum, and the final value was similar to that observed by Fresno et al. (1992) and Sánchez-Macías et al. (2010b) in milk from Majorera goats.

The $\mathrm{pH}$ displayed the lowest values at partum; after that, no differences were observed. Similar values and profiles have been described previously by Argüello et al. (2006) on goat colostrum. In cows, Tsioulpas et al. (2007) described lower values than observed in the present study during the first $5 \mathrm{~d}$ postpartum, but the d-90 $\mathrm{pH}$ values were similar in cows and goats. According to Edelsten (1988), $\mathrm{pH}$ values $<6.5$ in cow milk indicate the presence of some colostrum, although low $\mathrm{pH}$ values could also occur due to bacterial contamination. In the present study, the milk postpartum displayed the normal $\mathrm{pH}$ value for processing.

The titratable acidity profile postpartum showed a decrease of approximately $36 \%$ from partum to d 1 and after that, $26 \%$ more until d 90, in accordance with Güzeler et al. (2010). Titratable acidity measures components that exert some buffering capacity, in addition to lactic acid; these include proteins, phosphates, citrates, and carbon dioxide (Tsioulpas et al., 2007). Titratable acidity plays a fundamental role in all phases of milk coagulation, including the aggregation rate of paracasein micelles and the reactivity of rennet (De Marchi et al., 2009). The titratable acidity profile was inversely proportional to those of lactose and $\mathrm{pH}$.

Ethanol stability showed an irregular trend during the observed period, briskly decreasing at d 90. The ES values from the current study are much higher than those reported by Guo et al. (1998) who reported ES values of $44 \%$ in bulk goat milk. Goat milk has been found to have much lower ES than cow milk (44 vs. $70 \%$ ), mainly due to sodium and potassium balance. Guo et al. (1998) observed that the addition of sodium 
to goat milk increases the ES. Park et al. (2007), comparing goat, sheep, and cow milk, reported that goat milk has a higher $\mathrm{Ca}, \mathrm{P}, \mathrm{K}, \mathrm{Mg}$, and $\mathrm{Cl}$, and lower $\mathrm{Na}$ and $\mathrm{S}$ content than cow milk.

Colostrum samples did not clot at d 0, something that might be explained by the fact that colostrum contains a protease inhibitor that protects immunoglobulin from proteolytic damage in the gastrointestinal tract and during absorption (Sandholm and Honkanen-Buzalski, 1979). In addition, colostrum has more trypsin inhibitor than mature milk. Previous studies observed that trypsin secreted by the small intestine can degrade colostral antibodies (Quigley et al., 1995). After that, RCT displayed a decreasing pattern until d 90. Goat colostrum samples (first $5 \mathrm{~d}$ postpartum) should not be treated as milk for dairy applications, because their properties are different from normal, stable goat milk. Tsioulpas et al. (2007) observed that RCT was high on the first day, decreased sharply, remained constant for the next $3 \mathrm{~d}$, and then increased steadily, following a similar pattern to $\mathrm{pH}$ except on $\mathrm{d} 1$. Fox and McSweeney (1998) and Madsen et al. (2004) reported that RCT increases when $\mathrm{pH}$ increases and decreases when protein content increases. Results observed in the present study are opposite to those observed by Tsioulpas et al. (2007) after 5 d. These differences might be explained because according to Calvo (2002), the normal RCT for cows is $12 \mathrm{~min}$ and for goats is $7 \mathrm{~min}$.

Results of statistical analysis for SCC were not significantly different during the experimental time due to the high interanimal variability. The SCC was much higher in colostrum than in d-90 milk. This is in accordance with previous results in cows (Hallberg et al., 1995; Andrew, 2001; Ontsouka et al., 2003). Mastitis pathogens are not infrequently found in colostrum (Andrew, 2001), but no signs of clinical mastitis were observed in the experimental animals, and colostrum appearance was always normal according to the criteria described by Hallberg et al. (1995) for cows. After d 5, values for SCC in goat milk were in accordance with those previously reported in the same breed (SánchezMacías et al., 2010b). High SCC in colostrum in the current study was of a physiological nature, and it probably was most likely due to penetration of cells through leaky tight junctions between the mammary epithelial cells (Nguyen and Neville, 1998).

\section{Immunological Parameters}

Immunoglobulin G, IgA, and IgM concentrations and ChT activity profiles during the first $90 \mathrm{~d}$ of lactation are displayed in Table 3. The highest IgG colostrum concentration was observed at partum, and decreased quickly after that, as also reported by Moreno-Indias et al. (2012) during the first $10 \mathrm{~h}$ postpartum in the same breed, and by Castro et al. (2011a), studying the effect of induction of parturition on goat colostrum concentration of IgG. Also, Castro et al. (2011b) reviewed some management factors that affect to the colostrogenesis in small ruminants, reporting that via inactivation of IgG1-specific receptors on alveolar epithelial cells, the immunoglobulin transfer is downregulated by increasing prolactin during lactogenesis. On the other hand, kids are agammaglobulinemic at birth (Argüello et al., 2004); therefore, they need to be fed colostrum during the first hours after birth, as this is a principal IgG source during the first month of life. This information supports the idea that goat managers might use the first colostrum removed to provide a good immune passive transfer when colostrum bottle feeding is used, as well to avoid the induction of partum in goats.

The $\operatorname{IgA}$ and $\operatorname{IgM}$ profiles through lactation are similar to that described previously for IgG, decreasing fast in the $2 \mathrm{~d}$ after delivery. No references about the concentrations of $\operatorname{IgA}$ or IgM in goat colostrum or milk have been found in the literature. However, Moreno-Indias et al. (2012) observed a decrease in the first $10 \mathrm{~h}$ postpartum for both molecules (from 2.2 to $0-3$ and from 0.6 to $0.1 \mathrm{mg} / \mathrm{mL}$ for IgM and IgA, respectively), whereas Hernández-Castellano et al. (2011) found values of $0.08(\operatorname{IgM})$ and $0.03(\operatorname{IgA}) \mathrm{mg} / \mathrm{mL}$ for the period of early lactation. Recently, Abd El-Fattah et al. (2012), working with buffalos and cows, reported similar trends for IgG and IgM concentrations, with the values stabilizing at around 120 and $72 \mathrm{~h}$, respectively. Östensson and Lun (2008) stated that IgA in milk is produced from a local synthesis of mammary tissue, specifically in a place close to epithelial tissues of the udder. However, it is necessary to investigate deeply the origin of $\operatorname{IgA}$ and $\operatorname{IgM}$ in colostrum and the role of these 2 immunoglobulins in the newborn ruminant, because Rodríguez et al. (2009) demonstrate that these immunoglobulins are absorbed by newborn goat kids.

The IgG content in milk is critical for some properties, leading to less-effective pasteurization (Maurice, 1979) or a decrease in the heat stability of milk, off-flavors in pasteurized milk, and decreased cheese yield and curd firmness linked to the increase in total soluble protein content (Feagan, 1979). However, no studies have been found relative to the repercussions of the IgA and IgM content on the milk characteristics.

Colostrum and milk ChT activity ranged from 2,775 $\mathrm{nmol} / \mathrm{mL}$ per hour at partum to $178 \mathrm{nmol} / \mathrm{mL}$ per hour at $90 \mathrm{~d}$ postpartum. Colostrum ChT activity was significantly greater at partum. Similarly, activity $1 \mathrm{~d}$ postpartum was less than at partum, as indicated previously by Moreno-Indias et al. (2012), measuring a reduction during the 10 first hours postpartum. A similar profile 


\section{西}

(N) Table 2. Values of volume, density, pH, ethanol stability (ES), titratable acidity (TA; mL of $111 \mathrm{M} \mathrm{NaOH} \mathrm{0),} \mathrm{rennet-clotting} \mathrm{time} \mathrm{(RCT),} \mathrm{and} \mathrm{SCC} \mathrm{of} \mathrm{colostrum} \mathrm{and} \mathrm{milk} \mathrm{samples}$ from partum to d 90 postpartum ( $=10$ Majorera-breed goats)

\begin{tabular}{|c|c|c|c|c|c|c|c|c|c|c|c|}
\hline \multirow[b]{2}{*}{ Item } & \multicolumn{10}{|c|}{ Days postpartum } & \multirow[b]{2}{*}{ SEM } \\
\hline & 0 & 1 & 2 & 3 & 4 & 5 & 15 & 30 & 60 & 90 & \\
\hline Volume, mL & $2,358.57^{\mathrm{a}}$ & $696.43^{\mathrm{b}}$ & $1,278.57^{\mathrm{b}}$ & $1,389.29^{\mathrm{b}}$ & $1,464.29^{\mathrm{b}}$ & $1,553.57^{\mathrm{ab}}$ & $1,710.71^{\mathrm{ab}}$ & $1,939.29^{\mathrm{ab}}$ & $1,917.86^{\mathrm{ab}}$ & $1,838.79^{\mathrm{ab}}$ & 142.82 \\
\hline Density, $\mathrm{g} / \mathrm{mL}$ & $1.048^{\mathrm{a}}$ & $1.038^{\mathrm{b}}$ & $1.036^{\mathrm{bc}}$ & $1.032^{\mathrm{cd}}$ & $1.032^{\mathrm{cd}}$ & $1.033^{\mathrm{cd}}$ & $1.030^{\mathrm{cd}}$ & $1.029^{\mathrm{d}}$ & $1.028^{\mathrm{d}}$ & $1.028^{\mathrm{d}}$ & 0.006 \\
\hline $\mathrm{pH}$ & $6.40^{\mathrm{b}}$ & $6.61^{\mathrm{a}}$ & $6.68^{\mathrm{a}}$ & $6.66^{\mathrm{a}}$ & $6.64^{\mathrm{a}}$ & $6.65^{\mathrm{a}}$ & $6.66^{\mathrm{a}}$ & $6.75^{\mathrm{a}}$ & $6.70^{\mathrm{a}}$ & $6.71^{\mathrm{a}}$ & 0.09 \\
\hline $\mathrm{TA}, \mathrm{mL}$ & $4.2^{\mathrm{a}}$ & $2.7^{\mathrm{b}}$ & $2.2^{\mathrm{bc}}$ & $2.6^{\mathrm{bc}}$ & $2.2^{\mathrm{bc}}$ & $2.2^{\mathrm{bc}}$ & $1.6^{\mathrm{c}}$ & $1.5^{\mathrm{c}}$ & $1.5^{\mathrm{c}}$ & $1.6^{\mathrm{c}}$ & 0.08 \\
\hline $\mathrm{ES}, \%$ & $70.00^{\mathrm{ab}}$ & $63.43^{\mathrm{bc}}$ & $66.57^{\mathrm{ab}}$ & $72.86^{\mathrm{ab}}$ & $71.43^{\mathrm{ab}}$ & $76.29^{\mathrm{ab}}$ & $84.57^{\mathrm{a}}$ & $86.29^{\mathrm{a}}$ & $81.43^{\mathrm{ab}}$ & $55.33^{\mathrm{c}}$ & 9.21 \\
\hline $\mathrm{RCT}, \min$ & - & $16.6^{\mathrm{ab}}$ & $17.57^{\mathrm{a}}$ & $16.00^{\mathrm{ab}}$ & $14.14^{\mathrm{b}}$ & $10.14^{\mathrm{c}}$ & $6.57^{\mathrm{cd}}$ & $5.43^{\mathrm{cd}}$ & $3.43^{\mathrm{d}}$ & $2.67^{\mathrm{d}}$ & 5.6 \\
\hline $\mathrm{SCC}, \times 10^{3}$ cells & 8,449 & 6,539 & 4,624 & 4,828 & 2,983 & 1,433 & 804 & 467 & 458 & 846 & 2,697 \\
\hline
\end{tabular}

${ }^{\mathrm{a}-\mathrm{d}}$ Means within a row with different superscripts differ $(P<0.05)$.

Table 3. Immunoglobulin G, IgA, and IgM concentrations and chitotriosidase (ChT) activity of colostrum and milk samples from partum to d 90 postpartum (n = 10 Majorerabreed goats)

\begin{tabular}{|c|c|c|c|c|c|c|c|c|c|c|c|}
\hline \multirow[b]{2}{*}{ Item } & \multicolumn{10}{|c|}{ Days postpartum } & \multirow[b]{2}{*}{ SEM } \\
\hline & 0 & 1 & 2 & 3 & 4 & 5 & 15 & 30 & 60 & 90 & \\
\hline $\mathrm{IgG}, \mathrm{mg} / \mathrm{mL}$ & $32.99^{\mathrm{a}}$ & $20.13^{\mathrm{b}}$ & $8.23^{\mathrm{c}}$ & $6.05^{\mathrm{cd}}$ & $2.16^{\mathrm{d}}$ & $1.87^{\mathrm{d}}$ & $1.02^{\mathrm{d}}$ & $1.09^{\mathrm{d}}$ & $0.80^{\mathrm{d}}$ & $0.88^{\mathrm{d}}$ & 1.38 \\
\hline $\mathrm{IgA}, \mathrm{mg} / \mathrm{mL}$ & $0.86^{\mathrm{a}}$ & $0.40^{\mathrm{b}}$ & $0.24^{\mathrm{bc}}$ & $0.19^{\mathrm{bc}}$ & $0.17^{\mathrm{bc}}$ & $0.11^{\mathrm{c}}$ & $\begin{array}{l}1.02 \\
0.11^{\mathrm{c}}\end{array}$ & $0.12^{\mathrm{c}}$ & $0.10^{\mathrm{c}}$ & $0.07^{\mathrm{c}}$ & $\begin{array}{l}1.00 \\
0.04\end{array}$ \\
\hline $\mathrm{IgM}, \mathrm{mg} / \mathrm{mL}$ & $3.84^{\mathrm{a}}$ & $1.20^{\mathrm{b}}$ & $0.70^{\mathrm{bc}}$ & $0.59^{\mathrm{bc}}$ & $0.38^{\mathrm{c}}$ & $0.38^{\mathrm{c}}$ & $0.22^{\mathrm{c}}$ & $0.16^{\mathrm{c}}$ & $0.18^{\mathrm{c}}$ & $0.20^{\mathrm{c}}$ & 0.16 \\
\hline ChT activity, nmol/mL per hour & $2.775 .04^{\mathrm{a}}$ & $1.705 .73^{\mathrm{b}}$ & $741.90^{\mathrm{c}}$ & $591.48^{\mathrm{cd}}$ & $393.75^{\mathrm{cd}}$ & $337.85^{\mathrm{cd}}$ & $222.75^{\mathrm{d}}$ & $181.14^{\mathrm{d}}$ & $200.63^{\mathrm{d}}$ & $178.28^{\mathrm{d}}$ & 112.29 \\
\hline
\end{tabular}

${ }^{\mathrm{a}-\mathrm{d}}$ Means within a row with different superscripts differ $(P<0.05)$. 
was described by Argüello et al. (2008) and Castro et al. (2011a) up to 5 d postpartum. A similar decrease in colostrum ChT activity around partum was reported in humans by Musumeci et al. (2005), but ChT activity in human colostrum was lower than in goats, indicating that ChT might to play more of a protective role in goats than in humans. So, although the implication on goat kid immunity is clear, no implications have been described on the technological properties.

\section{CONCLUSIONS}

Goat colostrum at partum is richer in fat, protein, SCC, lactic acid, and immunity molecules than the subsequent secretions during early lactation. Goat colostrum is considered transitioned to milk after $5 \mathrm{~d}$, when all measured parameters are according to the normal ranges described in the literature for goat milk. From d 1 to 5, the secretion can be considered as transitional goat milk; it is not good colostrum due to the low immunological quality, although it is high in fat and protein content, and it is not good milk to use for dairy processing because of the high RCT, acidity, and immunoglobulin content. However, pouring transitional milk of 1 or 2 does into the bulk milk tank $3 \mathrm{~d}$ postpartum could result in a dilution of its components without inconvenience for dairy processing. This assumption must be evaluated for practical purposes in the future.

\section{REFERENCES}

Abd El-Fattah, A.M., F. H. R. Abd Rabo, S. M. EL-Dieb, and H. A. El-Kashef. 2012. Changes in composition of colostrum of Egyptian buffaloes and Holstein cows. BMC Vet. Res. 8:19.

Akinsoyinu, A. O., O. O. Tewe, and A. U. Mba. 1979. Concentration of trace elements in milk of West African dwarf goats affected by state of lactation. J. Dairy Sci. 62:921-924.

Andrew, S. M. 2001. Effect of composition of colostrum and transition milk from Holstein heifers on specificity rates of antibiotic residue tests. J. Dairy Sci. 84:100-106.

Arain, H. H., M. Khaskheli, M. A. Arain, A. H. Soomro, and A. H. Nizamani. 2008. Heat stability and quality characteristics of postpartum buffalo milk. Pakistan J. Nutr. 7:303-307.

Argüello, A. 2011. Trends in goat research, a review. J. Appl. Anim. Res. 39:429-434.

Argüello, A., N. Castro, S. Álvarez, and J. Capote. 2006. Effects of the number of lactations and litter size on chemical composition and physical characteristics of goat colostrum. Small Rumin. Res. 64:53-59.

Argüello, A., N. Castro, M. Batista, I. Moreno-Indias, A. MoralesdelaNuez, D. Sanchez-Macias, E. Quesada, and J. Capote. 2008. Chitotriosidase activity in goat blood and colostrum. J. Dairy Sci. 91:2067-2070.

Argüello, A., N. Castro, M. J. Zamorano, A. Castroalonso, and J. Capote. 2004. Passive transfer of immunity in kid goats fed refrigerated and frozen goat colostrum and commercial sheep colostrum. Small Rumin. Res. 54:237-241.

Calvo, M. M. 2002. Influence of fat, heat treatments and species on milk rennet clotting properties and glycomacropeptide formation. Eur. Food Res. Technol. 214:182-185.
Capote, J. 1999. Efecto de la influencia de ordeño en las características morfológicas, productivas y de facilidad de ordeño en cabras de la Agrupación Caprina Canaria. PhD Thesis. Universidad de Las Palmas de Gran Canaria, Arucas, Spain.

Castro, N., J. Capote, M. Batista, R. M. Bruckmaier, and A. Argüello. 2011a. Effects of induced parturition in goats on immunoglobulin $\mathrm{G}$ and chitotriosidase activity in colostrum and plasma and on plasma concentration of prolactin. Domest. Anim. Endocrinol. 40:192-196.

Castro, N., J. Capote, R. M. Bruckmaier, and A. Argüello. 2011b. Management effects on colostrogenesis in small ruminants: A review. J. Appl. Anim. Res. 39:85-93.

Chen, J. C., C. J. Chang, H. C. Peh, and S. Y. Chen. 1998. Total protein and $\gamma$-globulin contents of mammary secretion during early post-partum period of Nubian goats in the Taiwan area. Small Rumin. Res. 31:67-73.

Csapó, J., Z. Csapó-Kiss, T. G. Martin, J. Szentpeteri, and G. Wolf. 1994. Composition of colostrum from goats, ewes and cows producing twins. Int. Dairy J. 4:445-458.

Delgado-Pertíñez, M., J. L. Guzmán-Guerrero, F. P. Caravaca, J. M. Castel, F. A. Ruiz, P. González-Redondo, and M. J. Alcalde. 2009. Effect of artificial vs. natural rearing on milk yield, kid growth and cost in Payoya autochthonous dairy goats. Small Rumin. Res. $84: 108-115$.

De Marchi, M., C. C. Fagan, C. P. O'Donnell, A. Cecchinato, R. Dal Zotto, M. Cassandro, M. Penasa, and G. Bittante. 2009. Prediction of coagulation properties, titratable acidity, and $\mathrm{pH}$ of bovine milk using mid-infrared spectroscopy. J. Dairy Sci. 92:423-432.

Edelsten, D. 1988. Composition of milk. Pages 175-199 in Meat Science, Milk Science and Technology. H. R. Cross and A. J. Overby, ed. Elsevier Science Publishers B.V., Amsterdam, the Netherlands.

Feagan, J. T. 1979. Factors affecting protein composition of milk and their significance to dairy processing. Aust. J. Dairy Technol. $34: 77-81$.

Fox, P. F., and P. L. H. McSweeney. 1998. Dairy Chemistry and Biochemistry. 1st ed. Blackie Academic and Professional, London, UK.

Fresno, M., P. Martin, J. Capote, N. Darmanin, M. Corbella, and C. Casanova. 1992. Calidad media de la leche de la Agrupación Caprina Canaria durante la primera lactación. Avances en Alimentación y Mejora Animal 31:19-20.

Graf, F., K. Osterkorn, J. Fautz, K. Frahm, and C. Gall. 1970. Calorific value of goats' milk. I Relationship between fat and calorific value. Arb. Inst. Tierzücht., Vererbungs-u. Konstitutionsfor. Univ. München, Munich, Germany. 8:45-52.

Guo, M. R., S. Wang, Z. Li, J. Qu, L. Jin, and P. S. Kindsted. 1998. Ethanol stability of goat's milk. Int. Dairy J. 8:57-60.

Güzeler, N., D. Say, and A. Kaçar. 2010. Compositional changes of Saanen $\times$ Kilis goats' milk during lactation. Gida 35:325-330.

Hadjipanayiotou, M. 1995. Composition of ewe, goat and cow milk and of colostrum of ewes and goats. Small Rumin. Res. 18:255-262.

Hallberg, J. W., K. J. Dame, S. T. Chester, C. C. Miller, L. K. Fox, J. W. Pankey, S. C. Nickerson, and L. J. Weaver. 1995. The visual appearance and somatic cell count of mammary secretions collected from primigravid heifers during gestation and early postpartum. J. Dairy Sci. 78:1629-1636.

Hernández-Castellano, L. E., A. Torres, A. Alavoine, M. D. Ruiz-Díaz, A. Argüello, J. Capote, and N. Castro. 2011. Effect of milking frequency on milk immunoglobulin concentration (IgG, IgM and $\operatorname{IgA}$ ) and chitotriosidase activity in Majorera goats. Small Rumin. Res. 98:70-72.

Laakso, P., P. Manninen, J. Mäkinen, and H. Kallio. 1996. Postparturition changes in the triacylglycerols of cow colostrum. Lipids 31:937-943.

Linzell, J. L., and M. Peaker. 1974. Changes in colostrum composition and in the permeability of the mammary epithelium at about the time of parturition in the goat. J. Physiol. 243:129-151.

Madsen, B. D., M. D. Rasmussen, M. O. Nielsen, L. Wiking, and L. B. Larsen. 2004. Physical properties of mammary secretions in relation to chemical changes during transition from colostrum to milk. J. Dairy Res. 71:263-272. 
Maurice, L. 1979. Recherche du colostrum dans les fournitures de lait et incidences en industrie laitière. (Search for colostrum in milk deliveries and effects in dairy industries). Mémoire ESITPA, Le Vaudreuil, France. (in French)

Moreno-Indias, I., D. Sánchez-Macías, N. Castro, A. Morales-delaNuez, L. E. Hernández-Castellano, J. Capote, and A. Argüello. 2012. Chemical composition and immune status of dairy goat colostrum fractions during the first $10 \mathrm{~h}$ after partum. Small Rumin. Res. 103:220-224.

Musumeci, M., L. Malaguarnera, J. Simpore, R. Barone, M. Whalen, and S. Musumeci. 2005. Chitotriosidase activity in colostrum from African and Caucasian women. Clin. Chem. Lab. Med. 43:198 201.

Nguyen, D.-A. D., and M. C. Neville. 1998. Tight junction regulation in the mammary gland. J. Mammary Gland. Biol. Neoplasia $3: 233-246$.

Ontsouka, C. E., R. M. Bruckmaier, and J. W. Blum. 2003. Fractionized milk composition during removal of colostrum and mature milk. J. Dairy Sci. 86:2005-2011.

Östensson, K., and S. Lun. 2008. Transfer of immunoglobulins through the mammary endothelium and epithelium and in the local lymph node of cows during the initial response after intramammary challenge with E. coli endotoxin. Acta Vet. Scand. 50:26.

Park, Y. W., M. Juárez, M. Ramos, and G. F. W. Haenlein. 2007 Physico-chemical characteristics of goat and sheep milk. Small Rumin. Res. 68:88-113.

Pritchett, L. C., C. C. Gay, T. E. Besser, and D. D. Hancock. 1991 Management and production factors influencing immunoglobulin $\mathrm{G}_{1}$ concentration in colostrum from Holstein Cows. J. Dairy Sci. 74:2336-2341.

Quigley, J. D., H. H. Dowlen, and K. R. Martin. 1995. Concentrations of trypsin inhibitor and immunoglobulins in colostrum of Jersey cows. J. Dairy Sci. 78:1573-1577.

Quigley, J. D., K. R. Martin, H. H. Dowlen, L. B. Wallis, and K. Lamar. 1994. Immunoglobulin concentration, specific gravity, and nitrogen fractions of colostrum from Jersey cattle. J. Dairy Sci $77: 264-269$

Raynal-Ljutovac, K., P. Gaborit, and A. Lauret. 2005. The relationship between quality criteria of goat milk, its technological properties and the quality of the final products. Small Rumin. Res. 60:167-177.

Rodríguez, C., N. Castro, J. Capote, A. Morales-delaNuez, I. MorenoIndias, D. Sánchez-Macías, and A. Argüello. 2009. Effect of colostrum immunoglobulin concentration on immunity in Majorera goat kids. J. Dairy Sci. 92:1696-1701.

Rudovsky, A., L. Locher, A. Zeyner, A. Sobiraj, and T. Wittek. 2008. Measurement of immunoglobulin concentration in goat colostrum. Small Rumin. Res. 74:265-269.

Sanchez-Macias, D., N. Castro, I. Moreno-Indias, A. Morales-delaNuez, H. Briggs, J. Capote, and A. Argüello. 2010a. The effects of storage temperature on goat milk somatic cell count using the DeLaval counter. Trop. Anim. Health Prod. 42:1317-1320.

Sánchez-Macías, D., M. Fresno, I. Moreno-Indias, N. Castro, A. Morales-delaNuez, S. Álvarez, and A. Argüello. 2010b. Physicochemical analysis of full-fat, reduced-fat, and low-fat artisan-style goat cheese. J. Dairy Sci. 93:3950-3956.

Sandholm, M., and T. Honkanen-Buzalski. 1979. Colostral trypsin-inhibitor capacity in different species. Acta Vet. Scand. 20:469-476.

Suchanek, B., F. Sebela, and B. Picmanova. 1978 Effect of colostrum admixture on technological properties of milk. Page 747 in Proc. 20th Int. Dairy Congress, Paris, France. Int. J. Dairy Technol., Paris, France.

Tsioulpas, A., A. S. Grandison, and M. J. Lewis. 2007. Changes in physical properties of bovine milk from the colostrum period to early lactation. J. Dairy Sci. 90:5012-5017.

Zawistowski, J., and R. Mackinnon. 1993. Incidence of colostrum in raw milk. J. Food Prot. 56:625-626. 